\title{
Spatial Relationship Between Atrial Fibrillation Drivers and the Presence of Repetitive Conduction Patterns Using Recurrence Analysis on In-Silico Models
}

Citation for published version (APA):

Gonçalves Marques, V., Gharaviri, A., Pezzuto, S., Bonizzi, P., Zeemering, S., \& Schotten, U. (2021). Spatial Relationship Between Atrial Fibrillation Drivers and the Presence of Repetitive Conduction Patterns Using Recurrence Analysis on In-Silico Models. In 2021 Computing in Cardiology (CinC) (Vol. 48, pp. 1-4). The IEEE. Computing in Cardiology Vol. 48

https://doi.org/10.23919/cinc53138.2021.9662692

Document status and date:

Published: 01/01/2021

DOI:

10.23919/cinc53138.2021.9662692

Document Version:

Publisher's PDF, also known as Version of record

Document license:

Taverne

Please check the document version of this publication:

- A submitted manuscript is the version of the article upon submission and before peer-review. There can be important differences between the submitted version and the official published version of record.

People interested in the research are advised to contact the author for the final version of the publication, or visit the DOI to the publisher's website.

- The final author version and the galley proof are versions of the publication after peer review.

- The final published version features the final layout of the paper including the volume, issue and page numbers.

Link to publication

\footnotetext{
General rights rights.

- You may freely distribute the URL identifying the publication in the public portal. please follow below link for the End User Agreement:

www.umlib.nl/taverne-license

Take down policy

If you believe that this document breaches copyright please contact us at:

repository@maastrichtuniversity.nl

providing details and we will investigate your claim.
}

Copyright and moral rights for the publications made accessible in the public portal are retained by the authors and/or other copyright owners and it is a condition of accessing publications that users recognise and abide by the legal requirements associated with these

- Users may download and print one copy of any publication from the public portal for the purpose of private study or research.

- You may not further distribute the material or use it for any profit-making activity or commercial gain

If the publication is distributed under the terms of Article $25 \mathrm{fa}$ of the Dutch Copyright Act, indicated by the "Taverne" license above, 


\title{
Spatial Relationship Between Atrial Fibrillation Drivers and the Presence of Repetitive Conduction Patterns Using Recurrence Analysis on In-Silico Models
}

\author{
Victor G Marques, Ali Gharaviri, Simone Pezzuto, Pietro Bonizzi, Stef \\ Zeemering, Ulrich Schotten \\ Maastricht University, Maastricht, Netherlands
}

Aim: The outcome of catheter ablation for treatment of atrial fibrillation (AF) is still suboptimal, possibly due to the difficulty to identify AF drivers in the atria. Recurrence analysis is a technique that can be applied to detect the repetitive patterns that arise from organized conduction related to AF drivers and could be a valuable tool in their localization. In the present study, we aimed to understand the spatial relationship between repetitive patterns detected by recurrence analysis and the presence of rotors in an in-silico AF model.

Methods: AF was simulated in a detailed, high-resolution, three-dimensional model of the human atria, from which transmembrane potentials and electrograms (EGM) were obtained. The dataset consisted of 12 30-second AF simulations initiated by incremental pacing at different locations, with $70 \%$ of the atria composed of fibrotic cells distributed in patches. Phase singularities (PS), associated with rotors, were detected by analyzing phase differences in transmembrane potentials along the neighbors of each point in the anatomy. Simulated $4 \times 4$ electrode grids ( $3 \mathrm{~mm}$ spacing) were used to measure the EGMs of 15 regions in both atria. Recurrence plots (RP) were built from activationphase signals obtained from the EGMs and diagonal line lengths were calculated to characterize the repetitive patterns. The distance between PSs and each electrode array was used to correlate the observed RPs with the rotor position.

Results: Continuous repetitive patterns were detected predominantly in electrode arrays close to the tail of the rotors, whereas discontinuous diagonal lines appeared when the tip of the rotor was moving directly underneath or close to the array. Distant electrode arrays presented recurrent patterns less frequently.

Conclusion: recurrent patterns identified from RPs seem to correlate with the localization of AF drivers, and may be used to guide ablation therapy.

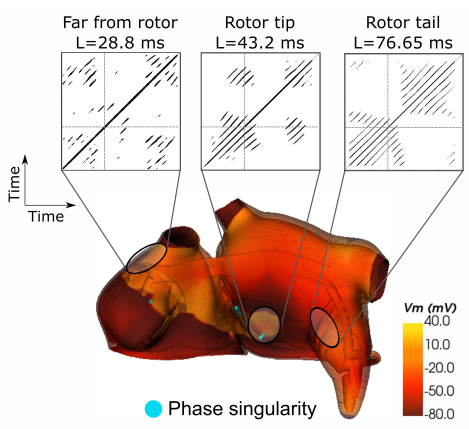

Recurrence plot $(2.5 \mathrm{~s})$ patterns and rotor location (L: mean diagonal line length) 